\title{
MASSES, TURBO-CAPITALISM AND POWER IN JEAN BAUDRILLARD'S SOCIAL AND POLITICAL ONTOTHEOLOGY
}

\author{
PhD. Prof. Spiros MAKRIS \\ Assistant Professor in Political Theory \\ University of Macedonia, Thessaloniki, \\ GREECE \\ Email: smakris@uom.gr
}

\begin{abstract}
If postmodern Jean Baudrillard (1929-2007) could be defined as a theorist of power - to the extent that for some this is a contradiction by definition, although something very similar takes place in the case of Michel Foucault, he could be defined as a theorist of meta-power in the globalized era of turbo-capitalism. In his late texts (2005), which were published in 2010, the eminent French philosopher builds a provocative theory about power by using the classic concepts of domination and hegemony within the contemporary social, economic, political and ideological context of neoliberal globalization. In these papers, he analyzes in-depth the metapower of hegemony in comparison with the power of domination. Actually, by signifying the critical passage of postwar capitalism from the phase of production to the phase of consumption, as Zygmunt Bauman does in his relevant work, Baudrillard formulates a meta-power theory as the equivalent of what he defines as turbo-capitalism. What is at stake is no longer the conventional issues of state sovereignty, Marx-inspired concept of alienation and Critical Theory-like negative dialectics but the crucial questions of hegemony, hostage and evilness. In short, Jean Baudrillard builds a new ontological and by extension disciplinary and theoretical field concerning global power, where the 'Empire of Good', or turbo-capitalism in his own terminology, is reborn in a totally catastrophic way (see simulation in the sense of a capitalist hypocrisy) either as an 'Axis of Evil' or as the 'problem of terror' (see simulacrum in the sense of a Lacanian stage of image within which turbo-capitalism represses, through a Freudian process of repelling, its unfamiliar self/i.e. uncanny, unheimlich). Despite the fact that Baudrillard has been sharply critisized for a kind of (apolitical) political pessimism, we strongly argue that, in a pure postmodern sense, Baudrillard illustrates power as a relational and absolutely dynamic, liquid and ambivalent space of antagonism, full of forces and counterforces. In the final analysis, he approaches power as an empty space, as in the similar case of Claude Lefort, open-ended, contingent, without certainties, within an ontological, anthropological and historical context which is characterized of high risk and an abyssal post-foundationalism. In this article, we thoroughly explore this novel and innovative Baudrillardian theoretical frame of power analysis and its potentialities for a New Critical Theory in the 21st century.
\end{abstract}

Keywords: ontotheology; masses; power; turbo-capitalism; metaphysics; pataphysics: 


\section{METAPHYSICS, PATAPHYSICS AND THE SOCIAL AS TRANSPARENT EVIL}

Jean Baudrillard is not probably a prophet of a pure theological style or a conventional fortune teller but without doubt his totally reflective thought from 1970s onwards until he passed away at the end of 2000s has a chiefly prophetic character. This is quite true, especially when we are looking for a novel and virtually radical social and political ontotheology which goes beyond the banalities of the mainstream politics and political thought as well. Having this concrete perspective as a basic point of theoretical and reflexive departure, in this article we perceive the famous French thinker Jean Baudrillard as an anticonventional social and political philosopher who radically and thoroughly deals with the key-questions of mass society, (anti and/or meta)power, (turbo)capitalism, consumerism and by extension neoliberal globalization within the historical context of postwar Western societies $^{1}$.

From the very beginning of his seminal bibliography and in a clearly prophetic and sometimes nearly messianic (but without messianicity, in the sense of the relevant Derridean thesis) ${ }^{2}$ and eschatological way as it is mentioned above, the prolific French (we dare say) anti-philosopher drew our attention on how a critical transition from production to seduction or, in a more sociologically conventional terminology, from the political economy of commodities to the political economy of signs took place throughout the postwar years in the contemporary Western societies. As it is well-known, Jean Baudrillard defined this absolutely new historical post-capitalist context using the almost poetic concepts of hyperreal and hyperreality ${ }^{3}$.

If we should specifically name a pioneer figure within the intellectual ranks of Continental Philosophy concerning the so-called "linguistic turn",4, undoubtedly this must be the French anti-philosopher Jean Baudrillard. The very crucial transition of contemporary Western societies from capitalist commodities' period to a period of an explosive symbolic order of empty signifiers, ${ }^{5}$, or whatever Jean Baudrillard termed as the ecstasy of communication $^{6}$, meaning by this notion mainly the advent of a new form of [capitalist] schizophrenia or late capitalism itself as the pure realization of a collective schizophrenia ${ }^{7}$, has led to the complicated and tricky phenomenon of turbo-capitalism, where the traditional necessity of a revolutionary social and political agent, as primarily happens with the Marxist argumentation, gave its position to the controversial question of masses as a new paradoxical historical quasi-subject and subsequently to the relevant problem of the end of the social ${ }^{8}$.

\footnotetext{
${ }^{1}$ Douglas Kellner, “Theorizing Globalization', In: Sociological Theory, No. 3, Vol. 20 (2002), pp. 285-305.

2 Spiros Makris, "Politics, Ethics and Strangers in the $21^{\text {st }}$ Century. Fifteen critical reflections on Jacques Derrida's concept of hos(ti)pitality”, In: Theoria \& Praxis. International Journal of Interdisciplinary Thought, No. 1, Vol. 5 (2017), pp. 1-21.

${ }^{3}$ Jean Baudrillard, Selected Writings, Polity Press, Cambridge, 1988 (Edited by Mark Poster).

${ }^{4}$ Michael Roberts, "Postmodernism and the linguistic turn', In: Peter Lambert and Phillipp Schofield (eds), Making History: An Introduction to the history and practices of a discipline, Routledge, Oxford and New York, 2004, p. 227.

${ }_{6}^{5}$ Ernesto Laclau, Emancipation(s), Verso, London and New York, 1996, p. 36.

6 Jean Baudrillard, "The Ecstasy of Communication', In: Hal Foster (ed.), The Anti-Aesthetic. Essays on Postmodern Culture, Bay Press, Port Townsend, Washington, 1987, pp. 126-134 (Translated by John Johnston).

7 Jean Baudrillard, “The Ecstasy of Communication', In: Hal Foster (ed.), The Anti-Aesthetic. Essays on Postmodern Culture, Bay Press, Port Townsend, Washington, 1987, p. 132 (Translated by John Johnston).

${ }^{8}$ Jean Baudrillard, In the Shadow of the Silent Majorities Or The End Of The Social, Semiotext(e), Los Angeles, 2007, p. 77 (Translated by Paul Foss, John Johnston, Paul Patton and Andrew Berardini).
} 
Nevertheless and of course again in a paradoxical way, especially when we take seriously into consideration how completely paradoxical is the Baudrillardian thought as such, the end of the social in the era of masses and turbo-capitalism does not signify but the end of the human emancipation and/or liberation as the two dominant questions and/or stakes which obsessively stigmatized the historical phase of capitalist modernity not only according to the Marxists but even to the opposite philosophical terrain of radical liberalism ${ }^{9}$. This is how we made here the decision to both outline and classify him as the ideal personification of anti-philosopher within contemporary Western social and political thought. Drawing the socio-political center of gravity far beyond emancipation and liberation (and so alienation), actually Jean Baudrillard brings to the fore the ontotheological horizon of a new paradoxical nearly absurd metaphysics, i.e. pataphysics, where the social is seen as an ecstatic and/or explosive reality more real that the conventional and tangible materiality ${ }^{10}$. In this vein, it could be strongly argued that Jean Baudrillard seems like a sui generis neo-Platonic thinker in the sense that introduces a new genre of metaphysics beyond the well-known traditional one. Matthias Benzer points out that "Baudrillard plays on metaphysics without renouncing his distance from it" $" 11$.

In Baudrillardian terms: "We are no longer a part of the drama of alienation; we live in the ecstasy of communication", 12 . As a matter of fact, this is a new sort of drama (we dare argue here that this is the postmodern drama in itself) where humans are entrapped by themselves (and this is the main paradoxical ontotheological feature of the masses in the late capitalism and/or turbo-capitalism) in the political economy of the empty and/or floating signifiers. This is exactly the Baudrillardian definition of parody. Adopting a radical Nietzsche-like viewpoint, full of absurdism, paradoxes, irony, parody, pastich and rhetorical poetics, Jean Baudrillard draws our attention not to the typical institutional (i.e. surficial) aspects of politics (which in one way or another is the conventional wisdom of mainstream Political Science) but to the ontotheological and (in his own poetical jargon) pataphysical dimensions of consumer society ${ }^{13}$.

In affluent societies a constitutive transition takes place from exploitation and war (i.e. domination) to knowledge and power (i.e. hegemony). Nonetheless, this critical historical and chiefly socio-political transition does not mean less violence ${ }^{14}$. Paradoxically, and this is another one of the plenty Baudrillardian paradoxes, within this seemingly non-violent structure appears the phenomenon (or spirit in his own lexicon) of terrorism as the inner face of the whole post-capitalist system. He writes in his stunning poetic style the following: "More than violence, indeed, we should speak of virulence. This violence is viral: it operates by contagion, by chain reaction, and it gradually destroys all our immunities and

${ }^{9}$ Ernesto Laclau, Emancipation(s), Verso, London and New York, 1996, p. 1.

10 Jean Baudrillard, The Conspiracy of Art. Manifestos, Interviews, Essays, Semiotext(e), New York, 2005 (Translated by Ames Hodges).

11 Matthias Benzer, 'Metaphysics', In: Richard G. Smith (ed.), The Baudrillard Dictionary, Edinburgh University Press, Edinburgh, 2005, p. 125.

12 Jean Baudrillard, "The Ecstasy of Communication', In: Hal Foster (ed.), The Anti-Aesthetic. Essays on Postmodern Culture, Bay Press, Port Townsend, Washington, 1987, p. 130 (Translated by John Johnston).

${ }^{13}$ Jean Baudrillard, The Consumer Society. Myths and Structures, Sage Publications, London, Thousand Oaks, New Delhi, 1999.

${ }^{14}$ Jean Baudrillard, The Consumer Society. Myths and Structures, Sage Publications, London, Thousand Oaks, New Delhi, 1999, p. 57. 
our power to resist" ${ }^{\prime \prime}$. In this case, Baudrillard's pataphysical approach sounds like Hannah Arendt's ontotheological, phenomenological and neo-republican theory about worldlessness and mass society in whatever she terms at the beginning as Totalitarianism and then as a post-Totalitarian era ${ }^{16}$.

By doing this, Jean Baudrillard throws the bright light on the critical role of mass media (as a poetical alliteration/parechesis of the masses) which substitute the traditional political institutions of representation by absorbing (like a monster; this paradoxical monster of masses or silent majorities) the social in the surface of a huge (TV-like) screen (that is to say virtual reality) which once more is ontologically, quasi-theologically and of course poetically termed with the nearly grisly concept of transparency of evil. Paraphrasing Baudrillard, it could be argued that media screen, as the realization of social emptiness, opens up a hole "in the mental universe". It is well-known that this paradoxical hole is just the crucial point that violence, or terror in the Baudrillardian terminology, appears as a transparent evil in the virtual-driven era of turbo-capitalism ${ }^{17}$.

Transparency of evil must be considered as a strong metonymy of pataphysics. According to Baudrillard, pataphysics is a kind of metaphysical emptiness. Actually, transparency indicates first and foremost this paradoxical emptiness where everything exists as an imaginery (i.e. virtual) statement. "Pataphysics", Jean Baudrillard writes "is the greatest temptation of the mind", 18 . Therefore, he argues, both exaggeration and ecstasy lead to the destruction and (in Derridean terminology) de(con)struction of reality. As far as the French anti-philosopher is concerned, pataphysics reveals a gaseous hyperreality, full of spiritual paroxysm, that looks almost like an empty place. We should bear in mind here that this is exactly the ontotheological way that Claude Lefort chooses to term the concept of power in the post-capitalist condition ${ }^{19}$. Above all, Jean Baudrillard points out, "there is only the pataphysic acid,"20.

In this respect, he adds with emphasis, pataphysics must be conceived as the "philosophy of the gaseous state" ${ }^{21}$. From this Baudrillardian viewpoint, everything is a tautology. It could be said that transparency, emptiness and tautology are just the poetical and rhetoric linguistic forms of an ontotheological existence without a real existent equivalent. Therefore, pataphysics seems like a "deadly narcissism, a mortal eccentricity" 22 . From this paradoxical ontotheological standpoint, world, capitalism, power and particularly

\footnotetext{
15 Jean Baudrillard, The Spirit of Terrorism, Verso, London and New York, 2012, p. 72 (Translated by Chris Turner).

${ }^{16}$ Hannah Arendt, The Origins of Totalitarianism, Schocken Books, New York, 2004; Hannah Arendt, Between Past and Future. Eight Exercises in Political Thought, Penguin Books, New York, 2006, p. 194 and Spiros Makris, "Aristotle in Hannah Arendt's Republicanism. From homo faber to homo politicus", In: Annuaire International De Droits De L' Homme, 2015-2016, Issy-les-Moulineaux Cedex, Paris: L.G.D.J. lextensoéditions, Volume IX (2017), pp. 535-563.

${ }^{17}$ Jean Baudrillard, The Transparency of Evil. Essays on Extreme Phenomena, Verso, London and New York, 1993, p. 75 (Translated by James Benedict).

${ }^{18}$ Jean Baudrillard, The Conspiracy of Art. Manifestos, Interviews, Essays, Semiotext(e), New York, 2005, p. 213 (Translated by Ames Hodges).

${ }^{19}$ Claude Lefort, Democracy and Political Theory, Polity Press, Cambridge, 1988, p. 17.

${ }^{20}$ Jean Baudrillard, The Conspiracy of Art. Manifestos, Interviews, Essays, Semiotext(e), New York, 2005 , p. 214 (Translated by Ames Hodges).

${ }^{21}$ Jean Baudrillard, The Conspiracy of Art. Manifestos, Interviews, Essays, Semiotext(e), New York, 2005, p. 214 (Translated by Ames Hodges).

22 Jean Baudrillard, The Conspiracy of Art. Manifestos, Interviews, Essays, Semiotext(e), New York, 2005 , p. 214 (Translated by Ames Hodges).
} 
the masses are considered now by Jean Baudrillard as kitsch or delirium. "In Pataphysics", he points out, "all phenomena are absolutely gaseous",23. By inspiring the pataphysic paradox, Baudrillard brings to focus (through the 'ecstasy of communication' or in more specific terms via the total and terroristic hegemony of mass media) the important phenomenon of the implosion of the masses in the era of turbo-capitalism. "The pataphysics", he poetically underlines, "is simply to burst",24.

In accordance with Baudrillard, postmodern capitalist world has entered a new historical era where power is just the metonymy of a collective suicide or "the stage of cruelty" 25 . More and more everything tends to be identified with this Heideggerian nothingness leading the silent masses until "the end of this world and of all possible worlds", 26 . Without doubt, this is the main point that due to it lots of scholars accuse Jean Baudrillard for a cold and scary pessimism, a Nietzsche-like political nihilism or a nearly apolitical stance against the neocapitalist condition of structural poverty and inhumane exploitation $^{27}$. But as far as our interpretation is concerned, this is not the appropriate interpretation of Baudrillardian social and political thought. Baudrillard, such as his spiritual mentor Antonin Artaud, creates and uses pataphysic acid as the ontotheological and linguistic (i.e. poetical) vehicle of a sui generis humor that gives us the theoretical devises to de(con)struct (and thus destruct) the new signs, signifiers and also contents of hegemonic power in the era of globalized capitalism ${ }^{28}$.

Hence, to sum up thus far, for the Baudrillardian masses to commit suicide means to demystify themselves. This both paradoxical and absurd self-catastrophic action of demystification is called by Baudrillard a bloodless process. However and despite the Nietzsche-like pessimistic character of this process, in the last analysis self-demystification could be considered as the regeneration of symbolic exchange in the deadly era of neocapitalist and/or neoliberal globalization ${ }^{29}$. To put it in a nutshell, through selfdemystification either individuals or especially the silent masses find out an ontotheological tactic to deal with and eventually grasp this totally new situation of post-capitalist implosion by using creatively and optimistically the humorous, parodic and finally sarcastic elements of self-assessment. Nonetheless this pataphysic method seems at first sight like a desperate

\footnotetext{
${ }^{23}$ Jean Baudrillard, The Conspiracy of Art. Manifestos, Interviews, Essays, Semiotext(e), New York, 2005 , p. 214 (Translated by Ames Hodges).

${ }^{24}$ Jean Baudrillard, The Conspiracy of Art. Manifestos, Interviews, Essays, Semiotext(e), New York, 2005 , p. 215 (Translated by Ames Hodges).

${ }^{25}$ Jean Baudrillard, The Conspiracy of Art. Manifestos, Interviews, Essays, Semiotext(e), New York, 2005, p. 215 (Translated by Ames Hodges).

${ }^{26}$ Jean Baudrillard, The Conspiracy of Art. Manifestos, Interviews, Essays, Semiotext(e), New York, 2005 , p. 215 (Translated by Ames Hodges).

${ }^{27}$ Ronaldo Munck, Marx @ 2000. Late marxist perspectives, Zed Books, London \& New York, 2000, p. 113; Paul Hegarty, “Jean Baudrillard”, In: Jon Simons (ed.), Contemporary Critical Theorists. From Lacan to Said, Edinburgh University Press, Edinburgh, 2004, p. 214; William Merrin, “Jean Baudrillard', In: John Scott (ed.), Fifty Key Sociologists. The Contemporary Theorists, Routledge, London and New York, 2007, p. 17; Ian Buchanan, Dictionary of Critical Theory, Oxford University Press, Oxford, 2010, p. 48; Stuart Sim, Fifty Key Postmodern Thinkers, Routledge, London and New York, 2013, p. 31 and Razmig Keucheyan, The Left Hemisphere. Mapping Critical Theory Today, Verso, London and New York, 2013, p. 58.

28 Jean Baudrillard, The Agony of Power, Semiotext(e), Los Angeles, 2010, p. 33 (Translated by Ames Hodges).

${ }^{29}$ Jean Baudrillard, Symbolic Exchange and Death, Sage Publications, London, Thousand Oaks, New Delhi, 1993 (Translated by Iain Hamilton Grant).
} 
step towards the "path to schizophrenia",30. Jean Baudrillard strongly argues that it is the only possible and perhaps efficient way to an earthly human salvation. From this perspective, if the paradoxical theologia negativa of pataphysics is the self-psychoanalysis of the masses in the era of turbo-capitalism (something like a redemptive seduction) then Baudrillard must be perceived also as a neo-Freudian ontotheological thinker ${ }^{31}$. In any case, both salvation and redemption as metonymies of self-seduction pave the way to a further analysis of Baudrillardian thought from the apocalyptic and messianic perspective of a negative theology in the sui generis poetical style of Franz Rosenzweig and Walter Benjamin $^{32}$.

\section{THE IMPLOSION OF THE MASSES, HEGEMONY AND THE PARADOX OF SELF-TERRORISM}

As far as Jean Baudrillard is concerned, from now on politics do not concern either the phenomenon of political representation or the question of revolutionary agency but the pataphysic manner within which the masses are transformed, through the mass media channels and the ecstasy of communication process, into a hyperreal space of perfect crime, that is to say the paradoxical space of self-de(con)struction or self-implosion. In this radical, ontotheological and poetical, framework, the French anti-philosopher resolves efficiently the traditional dualistic problem of good/evil or reality/illusion by providing an absolutely novel metaphysics or anti-metaphysics, i.e. pataphysics, in which the reality is nothing but a form of illusion $^{33}$.

"Events, real events", he emphatically points out, "will not even have time to take place. Everything will be preceded by its virtual realization. We are dealing with an attempt to construct an entirely positive world, expurgated of every illusion, of every sort of evil and negativity, exempt from death itself. This pure, absolute reality, this unconditional realization of the world - this is what I call the Perfect Crime (...) The situation is not simply contradictory or irrational - it is paradoxical. Beyond the end, beyond all finality, we enter a paradoxical state" where the excess of reality puts as a matter of fact an end to reality in itself; the excess of information puts and end to information and above all the excess of (especially human) communication puts an end to communication as such. Paradoxically, in this new ontotheological condition of turbo-capitalism and (a both powerful and powerless) hegemony, according to Jean Baudrillard, we do not suffer of a critical lack of reality but exactly from the opposite: we suffer of its critical self-fatal implosion ${ }^{34}$.

Baudrillard, in his astonishing poetic prosa and in purely Nietzschean terms, further claims that:

"the world would be a perfect crime, that is, a crime without a criminal, without a victim and without a motive (...) the perfection of the crime lies in the fact that it has always-already been accomplished - perfectum. A misappropriation of the world as it is, before it even shows itself. It will never, therefore, be discovered. There will be no Last

\footnotetext{
${ }^{30}$ Jean Baudrillard, The Conspiracy of Art. Manifestos, Interviews, Essays, Semiotext(e), New York, 2005 , p. 216 (Translated by Ames Hodges).

31 Jean Baudrillard, Seduction, St. Martin's Press, New York, 1990 and Richard J. Lane, Jean Baudrillard, London and New York, Routledge, 2001, p. 16.

${ }^{32}$ Franz Rosenzweig, The Star of Redemption, The University of Wisconsin Press, 2005; Walter Benjamin, Illuminations, The Bodley Head, London, 2015 and Richard J. Lane, Jean Baudrillard, London and New York, Routledge, 2001, p. 105.

33 Jonathan Smith, "Perfect Crime", In: Richard G. Smith (ed.), The Baudrillard Dictionary, Edinburgh University Press, Edinburgh, 2005, pp. 152-155.

${ }^{34}$ Jean Baudrillard, The Vital Illusion, Columbia University Press, New York, 2000, pp. 65-67.
} 
Judgment to punish or pardon it. There will be no end, because things have always-already happened. Neither resolution nor absolution, but inevitable unfolding of the consequences. Precession of the original crime which we might perhaps be said to find in the derisory form in the current precession of simulacra. After that, our destiny is the accomplishment of this crime, its inexorable unfolding, the continuity of the evil, the continuation of the nothing. We shall never experience the primal scene, but at every moment we experience its prolongation and its expiation. There is no end to this and the consequences are incalculable (...) This is the form the mystery takes'".

And by paraphrasing both Parmenides and Martin Heidegger, he concludes: "The great philosophical question used to be 'Why is there something rather than nothing?' Today, the real question is: 'Why is there nothing than something?,, 35 .

Therefore, it goes without saying, that the end of the social, as far as Jean Baudrillard is concerned, does not signify only the loss of [the traditional version of] politics, but in a sense the end of the well-known capitalist modernity in itself. In this regard, turbocapitalism, as the fundamental ontotheological and social form of the so called hyperpolitics, leads straight to the paradoxical chaos and abyss of self-terrorism. To cut a long story short, the French anti-philosopher primarily argues that "the social itself has died before having given up its secret",36. This is a very critical turning point in Baudrillardian ontotheological analysis having regard to the political modernity because actually he strongly declares the impossibility of revolution and socialism and mainly the definite end of class struggle and proletariat. All these ideas and agencies of modern capitalism now are replaced by the paradoxical and hyperreal (self-catastrophic) 'monster' of the (loudly silent) masses ${ }^{37}$.

At the ontotheological epicenter of this new hypersocial human condition is located the chaotic and abyssal phenomenon of a hegemonic power that simply guides the masses at the self-catastrophic moment of implosion. Thus, if both hegemony and masses represent a new duality or a new Manichaeism, undoubtedly this is a quasi-ontotheological duality where the traditional one-dimensional scene of the global History is transformed into a long and huge pataphysic continuum, without concrete poles, having the parodic and sarcastic form of an implosive polarity. It is well-known that in pure Baudrillardian terms this new postmodern (or post-capitalist) condition is considered as an abyss of meaning ${ }^{38}$ where the pessimistic and hopeless loss of any eschatological faith is replaced by a fatal polarity between masses and terrorism 39 . "In their triangular affinity", Baudrillard points out, "the masses, the media and terrorism describe the presently prevailing process of implosion (...) For us today', he continues in a purely messianic and no doubt prophetic jargon both in the sense of a new theologia negativa, "implosion can only be violent and catastrophic because it comes from the failure of the system of explosion [that is the system of political

\footnotetext{
${ }^{35}$ Jean Baudrillard, The Perfect Crime, Verso, London and New York, 1996, pp. 1-2 (Translated by Chris Turner).

${ }^{36}$ Jean Baudrillard, In the Shadow of the Silent Majorities Or The End Of The Social, Semiotext(e), Los Angeles, 2007, p. 94 (Translated by Paul Foss, John Johnston, Paul Patton and Andrew Berardini).

37 Jean Baudrillard, In the Shadow of the Silent Majorities Or The End Of The Social, Semiotext(e), Los Angeles, 2007, pp. 91-93 (Translated by Paul Foss, John Johnston, Paul Patton and Andrew Berardini).

38 Jean Baudrillard, In the Shadow of the Silent Majorities Or The End Of The Social, Semiotext(e), Los Angeles, 2007, p. 40 (Translated by Paul Foss, John Johnston, Paul Patton and Andrew Berardini).

39 Jean Baudrillard, In the Shadow of the Silent Majorities Or The End Of The Social, Semiotext(e), Los Angeles, 2007, p. 67 (Translated by Paul Foss, John Johnston, Paul Patton and Andrew Berardini).
} 
modernity] and of organized expansion which has predominated in the West now for a few centuries $" 40$.

Following in this great and innovative reflexive tradition which ranges from Rosa Luxemburg to Jürgen Habermas footsteps ${ }^{41}$, Baudrillard sees in the paradoxical phenomenon of mass (self)terrorism not merely the end of the social but virtually the self-catastrophic end of modern capitalist expansion itself. In this specific respect, turbo-capitalism represents the critical ontotheological moment of the absolute colonization of lifeworld by the hegemonic system. Although at a first sight this new historical conjuncture looks like the ideal moment of the arrogant neoliberal triumph (i.e. the 'Fukuyama syndrome') ${ }^{42}$, actually, for the antiphilosopher Jean Baudrillard, that is to say for this sceptical and anti-conventional spirit, this moment in fact signifies the moment that global neocapitalism has conquered everything (violently or not) and because of this has reached its deep ontotheological limits ${ }^{43}$.

As always, Baudrillard illustrates this new, we dare say, posthuman condition with an excellent almost poetic prosa:

"'Our 'modern' civilizations", he writes, "have existed on a base of expansion and explosion at all levels, under the sigh of universalized commerce, of economic and philosophical investments, under the sign of universal law and conquest. Undoubtedly, even they have known how to survive, for a time at least, on a controlled explosion, on a liberation of subdued and progressive energy, and this was the golden age of their culture. But, according to a process of boom and acceleration, this explosive process has become uncontrollable, it has acquired a fatal speed of amplitude, or rather it has reached the limits of the universal, it has saturated the field of possible expansion and, just as primitive societies were ravaged by explosion for not knowing how to curb the implosive process any longer, so our culture begins to be ravaged by implosion for not having known how to curb and equilibrate the explosive process" $" 44$.

Hence, for Baudrillard, the phenomenon of global terrorism must be seen as the heyday of turbo-capitalism. In other words, even though it is obviously a tragic fact with catastrophic implications for the contemporary societies, at the same time, at the symbolic level, as the first mark of a process of symbolic exchange that has restarted ${ }^{45}$, could be considered in Aristotelian terms as a cathartic event giving the global masses the chance for self-reflection and self-awareness. So, hegemonic power loses its traditional primacy and actually is transformed into the vehicle for a world that symbolically explodes from inside (i.e. implosion). As it is known quite well, the eminent French anti-philosopher did not face the thorny and controversial question of global terrorism as a typical socio-political problem in the postmodern era both of globalization and radicalization of religious fundamentalism but first and foremost as an ontotheological, existential and metaphysical question par

\footnotetext{
40 Jean Baudrillard, In the Shadow of the Silent Majorities Or The End Of The Social, Semiotext(e), Los Angeles, 2007, p. 73 (Translated by Paul Foss, John Johnston, Paul Patton and Andrew Berardini).

41 Spiros Makris, "European Demos, Citizenship and Migrants in a Globalized World. Some Critical Reflections from a Habermasian Perspective", In: Marco Caselli and Guia Gilardoni (eds), Globalization, Supranational Dynamics and Local Experiences, Palgrave Macmillan, New York, 2018, pp. 87-107.

42 David M. Kotz, The Rise and Fall of Neoliberal Capitalism, Harvard University Press, USA, 2015, p. 201.

43 Jean Baudrillard, In the Shadow of the Silent Majorities Or The End Of The Social, Semiotext(e), Los Angeles, 2007, pp. 66-73 (Translated by Paul Foss, John Johnston, Paul Patton and Andrew Berardini).

44 Jean Baudrillard, In the Shadow of the Silent Majorities Or The End Of The Social, Semiotext(e), Los Angeles, 2007, p. 74 (Translated by Paul Foss, John Johnston, Paul Patton and Andrew Berardini).

45 Jean Baudrillard, Symbolic Exchange and Death, Sage Publications, London, Thousand Oaks, New Delhi, 1993 (Translated by Iain Hamilton Grant).
} 
excellence, in the sense that he chiefly argues that the spirit of terrorism itself signifies the end of the social per $\mathrm{se}^{46}$. Masses are exploding from within not so as the result of either subordination or exploitation or alienation (which is the typical Marxist approach) but because they reach, through the ecstasy of communication, to the paradoxical condition of absolute transparency of a tautological evil. When the world meaning is empty of any content, the medium itself (i.e. the masses) willingly goes towards self-de(con)struction and in the last analysis self-implosion.

From this point of view, mass terrorism could be perceived whether as the metonymy of the masses or the metonymy of a capitalist system of domination which by trying to hegemonize upon everything comes to this acid situation of self-catastrophe. Terrorism, for Baudrillard, looks like a pataphysic virus that contaminates everything. In a poetic manner, the French anti-philosopher illustrates terrorism either as a double agent of global capitalism or like its deadly shadow. There is no longer a clear and obvious demarcation line between terrorism and hegemonic system. "It is at the very heart of this culture which combats it (...) That system", he clarifies with emphasis, "can face down any visible antagonism. But against the other kind, which is viral in structure (...) against that form of almost automatic reversion of its own power, the system can do nothing. And terrorism is the shock wave of this silent reversion, 47 .

To put it simply, this radical development means that to the extent that violence contaminates everything seemingly there is no longer violence. Nonetheless, transparency of evil or the visibility of an invisible pataphysic virus is finally the failure of the hegemonic system itself which leads almost deterministically to the fatal moment of mass implosion. However, is it really a fatal outcome or Jean Baudrillard provides us just with an awful sociological view of the so-called turbo-capitalism? Without doubt, this is a significant question that is raised especially by those scholars who strongly criticize Jean Baudrillard for political pessimism and apolitical stance in general. As mentioned above, the mainstream academic critique against pataphysic argumentation about the ontotheological status of contemporary society and politics is that Baudrillard must be perceived as an entirely apolitical and furthermore pessimist thinker. If we accept this approach, it is probable to miss the critical point concerning Baudrillardian thought as a conceptual and theoretical whole. For this reason and in order to constructively deal with this problématique, it is worth arguing here that he must not be classified on the basis of the ordinary case of social and political nihilism. Choosing the method of pataphysics and by extension the onto-theological form of simulacra, Jean Baudrillard brings to the fore a new genre of nihilism in which the simulated transparency of the masses (and so of the evil) is invested in the implosive condition of melancholia (Baudrillard, 1994: 162) ${ }^{48}$.

According to Jean Baudrillard, social and political melancholia is actually the paradoxical, implosive and cruel systemic (i.e. the hegemonic system against itself) displeasure in the dark and gloomy age of turbo-capitalism. Chiefly, it concerns the phenomenon that he terms as the abyss of meaning 49 . "Melancholia", Baudrillard stresses,

${ }^{46}$ Jean Baudrillard, The Spirit of Terrorism, Verso, London and New York, 2012 (Translated by Chris Turner).

${ }^{47}$ Jean Baudrillard, The Spirit of Terrorism, Verso, London and New York, 2012, p. 8 (Translated by Chris Turner).

${ }^{48}$ Jean Baudrillard, Simulacra and Simulation, The University of Michigan Press, Ann Arbor, 1994, p. 162 (Translated by Sheila Faria Glaser).

49 Jean Baudrillard, In the Shadow of the Silent Majorities Or The End Of The Social, Semiotext(e), Los Angeles, 2007, p. 40 (Translated by Paul Foss, John Johnston, Paul Patton and Andrew Berardini). 
"is the fundamental tonality (...) of current systems of simulation, of programming and information. Melancholia is the inherent quality of the mode of the disappearance of meaning, of the mode of the volatilization of meaning in operational systems (...) we are all melancholic. Melancholia is the brutal disaffection that characterizes our saturated systems ${ }^{,}, 50$.

Hence, we must take seriously into consideration the fact that this Baudrillard-inspired human condition of melancholia is neither a pure romanticist feeling nor a simple pessimistic attitude. In effect, melancholia is the metonymy of neocapitalist implosion. In other words, it must be perceived as the point zero of the social itself, when the transparent masses, being emptied from any political representation and ideological meaning, via an infinite coloniallike expansion, in the sense of a capitalist system that accelerates without any ethical restrictions (i.e. turbo-capitalism), finally end in the pataphysic situation of an energetic impasse; an explosive inertia; which both are hypostasized in the marginal ontotheological and phenomenological event of a tragic (or cathartic in the optimistic case scenario) existential self-disappearance. It is worth noting here that paradoxically the moment in which the hegemonic system feels so strong, at the same moment, paraphrasing Cornelius Castoriadis expression: "it reminds us that we forever live at the edge of the Abyss",51. In this vein, turbo-capitalism step by step approaches the edge of chaos; that is to say little by little enters into the post-foundational specter of self-dissolution ${ }^{52}$.

Considered from this point of view, melancholia á la Baudrillard could be seen as the pataphysic, paradoxical and parodic (the three 'P's) realization of neo-capitalist entropy per se. In particular, melancholia of the masses denotes just this paradoxical situation of the powerful but saturated system of turbo-capitalism in the ontotheological moment of its implosive self-aphanisis. Psychoanalytically speaking, it must be considered as the disappearance of any kind of desire. In other words, for Baudrillard, it clearly brings to the fore the disappearance of the social subject itself. This is exactly the paradox of pataphysic melancholia. The most exlposive moment of the masses represents at the same time the moment of their self-de(con)struction. Actually, this is the only ontotheological way to the social and political regeneration. The masses have to pay the price of a total entropy of the hegemonic system. So, it could be argued here that although masses, mass media and melancholia (the three ' $\mathrm{M}$ 's) construct a kind of hyperfinality, that the hegemonic system of turbo-capitalism creates on its own; by its suicide; by terrorizing itself; Baudrillard steadily believes that this systemic nihilism, in the sense of a social void; as a gigantic black hole; in the final analysis tragically undermines the hegemonic power until its final implosion and breakdown ${ }^{53}$.

This is exactly the precise meaning of this paradoxical, ontological, theological and in the last analysis symbolical situation that the eminent French antiphilosopher terms as fatal strategies, which is a combination or an intersection of ecstasy,

\footnotetext{
${ }^{50}$ Jean Baudrillard, Simulacra and Simulation, The University of Michigan Press, Ann Arbor, 1994, p. 50 (Translated by Sheila Faria Glaser).

${ }^{51}$ Cornelius Castoriadis, The Castoriadis Reader, Blackwell Publishers, Oxford, 1997, p. 346 (Translated by David Ames Curtis).

52 Jean Baudrillard, Simulacra and Simulation, The University of Michigan Press, Ann Arbor, 1994, p. 163 (Translated by Sheila Faria Glaser).

53 Jean Baudrillard, In the Shadow of the Silent Majorities Or The End Of The Social, Semiotext(e), Los Angeles, 2007, p. 36 (Translated by Paul Foss, John Johnston, Paul Patton and Andrew Berardini).
} 
inertia and irony ${ }^{54}$. At the epicenter of fatal strategies, Baudrillard poses the principle of $E_{v i l}{ }^{55}$ : a delirious world, i.e the masses in the era of turbo-capitalism and hegemonic power, which transforms, ironically, parodically and sarcastically, its voluntary servitude or obedience into a self-de(con)structive disobedience. Evil is just the critical ontotheological moment that silent masses (supposedly the absolute subject) become the absolute object. To put it differently, in the era of hyperreality, masses cease to be a social or a political subject in the conventional sense and become the fatality of the capitalist system itself ${ }^{56}$.

With his own words, Baudrillard is entirely clear and apocalyptic (here also with the messianic and eschatological sense of the word) by disclosing the (hyper)real content of power and politics in the era of turbo-capitalism. "We confuse", he writes, "the fatal with the resurgence of the repressed (desire as that which is inescapable), but the order of fatality is antithetical to that of repression. It is not desire that we cannot escape, but the ironic presence of the object, its indifference, and its indifferent interconnections, its challenge, its seduction, its violation of the symbolic order (therefore of the subject's unconscious as well, if it had one). In short, it is the principle of Evil we cannot escape" ${ }^{, 57}$. Actually, we cannot escape ourselves (that is to say our evil self). Everything now is transparent. In this respect, Jean Baudrillard introduces a Spinoza-like social and political ontotheology in which the masses, i.e. the Spinozian multitude, are the pure objectivity itself. In other words, the masses, or the silent majorities, as Baudrillard alternatively name them, are the real Hobessian sovereign: in other words an objectivity irreconcilable, immanent and enigmatic $^{58}$.

In this new global situation of today, as it is apparently illustrated by Jean Baudrillard, especially in his seminal book "In the Shadow of the Silent Majorities" (Baudrillard, $2007)^{59}$, having as an almost fatal data the fact of the lack of any political representation or social agency, turbo-capitalism leads hegemonic power to the pataphysic human condition of an ontotheological and further symbolic lethargy. In Nietzsche's lexicon, this could be perceived as the pure definition of tragic irony. To put it another way, this could be considered as a postmodern parody which neocapitalist modernity gives birth itself. In accordance with the eminent French anti-philosopher, silent majorities in the era of ecstasy of communication denote not just a typical capitalist contradiction (in Marxian terms) or a political dialectics (in Hegelian lexicon) but the ontotheological and rhetoric transparency of the hegemonic system itself $f^{60}$.

This new capitalist system, full of simulacra and simulations, running straight to Nowhere as a gigantic collective turbo-consumer, is no longer characterized by the wellknown traditional concrete ideological and/or ethical binary poles (e.g. left/right, right/wrong etc.). By contrast, it constitutes only an unstoppable cyclical polarity looking like the

\footnotetext{
${ }^{54}$ Jean Baudrillard, Fatal Strategies, Semiotext(e), Los Angeles, 2007, p. 25 and p. 97 (Translated by Philippe Beitchman \& W. G. J. Niesluchowski).

55 Jean Baudrillard, Fatal Strategies, Semiotext(e), Los Angeles, 2007, p. 219 (Translated by Philippe Beitchman \& W. G. J. Niesluchowski).

56 Jean Baudrillard, In the Shadow of the Silent Majorities Or The End Of The Social, Semiotext(e), Los Angeles, 2007, p. 55 (Translated by Paul Foss, John Johnston, Paul Patton and Andrew Berardini).

57 Jean Baudrillard, Selected Writings, Polity Press, Cambridge, 1988, p. 199 (Edited by Mark Poster).

58 Jean Baudrillard, Selected Writings, Polity Press, Cambridge, 1988, p. 199 (Edited by Mark Poster).

59 Jean Baudrillard, In the Shadow of the Silent Majorities Or The End Of The Social, Semiotext(e), Los Angeles, 2007 (Translated by Paul Foss, John Johnston, Paul Patton and Andrew Berardini).

${ }^{60}$ Jean Baudrillard, The Transparency of Evil. Essays on Extreme Phenomena, Verso, London and New York, 1993, p. 78 (Translated by James Benedict).
} 
Nietzschean process of eternal return ${ }^{61}$. As far as Jean Baudrillard is concerned, and without doubt this must be considered as his fundamental thesis on both the nature and function of hegemonic power in the age of globalization, by creating the silent masses, the capitalist system creates virtually the preconditions of its implosion; its decadence; its collapse. Actually, from this viewpoint, the French anti-philosopher, as a Marx's specter that perpetually haunts us in the late modernity, implicitly argues, of course in his quite poetic and at the same time, theologically speaking, messianic and eschatological vocabulary, that postmodern capitalism, in the final analysis, creates its gravedigger: "The development of large-scale industry", Marx aphoristically points out, "pulls from under the feet of the bourgeoisie the very foundations on which they produce goods and appropriate them. Above all it produces its own gravediggers", 62 .

Therefore, melancholia, apathy and inertia of the silent masses must be seen as the very critical moments of this hegemonic system of power, that is to say turbo-capitalism and its fatal strategies, which more and more, within a cyclic process of fatal overextensions (as in the case of the colonization of the lifeworld by the system in Jürgen Habermas's approach), tends to an enormous implosion which will destroy its hegemony and perhaps the world itself (obviously, this is the ecological aspect of the Baudrillardian theologia negativa in the sense of the Coppola's 'Apocalypse Now') ${ }^{63}$. By echoing to an extent the sound of conventional revolution, Baudrillard defines this new social and political condition as involution $^{64}$. In fact, the masses freeze the entire neocapitalist system. In the era of hyperreality, there are no longer social subjects or political agents. In contrast, there is only the object of the masses as a sui generis terroristic ghost (by reminding us once more the awful Marxian specter of communism) against the hegemonic power ${ }^{65}$. Following in closely the writing style of the Baudrillardian ontotheological poetics footsteps, it could be said here that this development in the late modernity is not but the other Hamletian face of the inhumane neocapitalist system as it is reflected in the transparent mirror of both Good and Evil.

As we have seen above, the traditional metaphysics of the social paves the way to a radical, ontotheological and rhetoric, theory of imaginary, i.e. pataphysics, to remember only Cornelius Castoriadis's relevant notion. From now on, everything is possible and the same time everything is quite impossible. Humor, fascination and seduction reveal (in the sense of an apocalyptic revelation without Messiah) the novel phenomenon of hyperpolitics as the transpolitical of hyperconformity ${ }^{66}$. Nevertheless, paradoxically and against the conventional wisdom, for Baudrillard, hyperconformity signifies a new kind of resistance beyond the mainstream eschatological narratives of emancipation, liberation and alienation (i.e. theologia positiva). By doing this, the French anti-philosopher builds a sort of theologia

${ }^{61}$ Friedrich Nietzsche, Thus Spoke Zarathustra, Penguin Books, London and New York, 1969, p. 176 (Translated by R. J. Hollingdale).

${ }^{62}$ Karl Marx, Later Political Writings, Cambridge, Cambridge University Press, 2002, p. 12 (Edited and translated by Terrell Carver).

63 Jean Baudrillard, Simulacra and Simulation, The University of Michigan Press, Ann Arbor, 1994, p. 59 (Translated by Sheila Faria Glaser).

${ }^{64}$ Jean Baudrillard, In the Shadow of the Silent Majorities Or The End Of The Social, Semiotext(e), Los Angeles, 2007, p. 67 (Translated by Paul Foss, John Johnston, Paul Patton and Andrew Berardini).

65 Jean Baudrillard, In the Shadow of the Silent Majorities Or The End Of The Social, Semiotext(e), Los Angeles, 2007, p. 122 (Translated by Paul Foss, John Johnston, Paul Patton and Andrew Berardini).

${ }_{66}$ Jean Baudrillard, In the Shadow of the Silent Majorities Or The End Of The Social, Semiotext(e), Los Angeles, 2007, p. 62 (Translated by Paul Foss, John Johnston, Paul Patton and Andrew Berardini). 
negativa according to which the crucial matter is no longer the class struggle but the inherently entropic nature of the turbo-capitalism itself.

Although there is a strong impression that Jean Baudrillard in his provocative essay "Forget Foucault" rejects Michel Foucault's theory of power as an abyssal system of actions and reactions ${ }^{67}$, in fact, it could be strongly argued that he leads this Foucauldian approach to its ontotheological and symbolic limits by turning both turbo-capitalism and hegemony into a thick space of networks and mass media within which the acceleration and proliferation of the gigantic social energy (i.e. meaning itself as a pure object) tends to negate and neutralize every form of hegemonic power. In this vein, as in the case of Foucault, Baudrillard could be reasonably characterized as a theoretician of anti-(and/or meta)-power in the era of globalization.

Hence, if we ought to sum up thus far this Baudrillardian pataphysic account of antimeta-power, it could be said that this theoretical approach, just opposite to the modern Marxist or even liberal approaches of emancipation, liberation and alienation, in which either a revolutionary social agent or a liberating political agency is placed at the heart of social and political process, perceives human resistance as an entropic byproduct of the hegemonic system itself and vice versa ${ }^{68}$. Therefore, against the strong seduction that causes people the ecstasy of communication and by extension the hyperconformity of turbo-capitalism, the seemingly silent masses, as the pure objectification of the implosion of the social, refuse both passively (involution) and actively (revolution) any total manipulation either from neocapitalist markets and the relevant marketing projects or from hegemonic powers or in the last analysis from any branch of the hegemonic system and its dominant signifiers.

For Jean Baudrillard, the masses connote the doubling logic of a hegemonic neocapitalist system which, as a transparent mirror of Evil, reflects itself by absorbing any kind of socio-political representation or agency. This abyssal polarity opens up a new ontotheological and symbolic space of reality, or the space of a new reality, more real than the real, i.e. hyperrreal, where power as hyperpolitics or as a transpolitical spectral entity is simultaneously a kind of anti-meta-power. Both power and the masses, as a mythical Janus, poetically speaking, look as a double-faced Hamletian specter which enters into the scene of the History as a twofold actor either in order to hegemonize over the masses or (and this is the innovative and provocative part of Baudrillard's anti-meta-power theory) to be put under question by the masses: in pure Shakespearean terms to be put 'out of joint'. In this perspective, the masses are not a typical passive subject (i.e. object) but a pataphysic entity which has the ability to open up some cracks in the hegemonic capitalist system; to de(con)struct it; and by doing this either to cause some important reformations or even its breakdown. This is why, as aforementioned, Jean Baudrillard's pessimism is not a mainstream theoretical approach but an entire anti-philosophical interpretation of the late modernity as a whole ${ }^{69}$.

\section{THE AGONY OF HEGEMONIC POWER OR THE ABYSSAL POWER OF HUMAN AGONY}

This Baudrillardian ontotheology of anti-meta-power, which in conventional jargon could be seen as a radical theory of civil disobedience in the era of neoliberal globalization ${ }^{70}$,

\footnotetext{
${ }^{67}$ Jean Baudrillard, Forget Foucault, Semiotext(e), Los Angeles, 2007 (Translated by Nicole Dufresne).

68 Jean Baudrillard, In the Shadow of the Silent Majorities Or The End Of The Social, Semiotext(e), Los Angeles, 2007, p. 102 (Translated by Paul Foss, John Johnston, Paul Patton and Andrew Berardini).

${ }^{69}$ Paul Hegarty, Jean Baudrillard. Live Theory, Continuum, London, New York, 2004, p. 155.

${ }^{70}$ Hannah Arendt, Crises of the Republic, Harcourt Brace Jovanovich, Inc., New York, 1972, p. 49.
} 
finally is summarized by the late Baudrillard in a couple of critical texts that the French antiphilosopher wrote about 2005 and which, in 2010, three years after he has passed away, they published under the semiologic and enlightening title "The Agony of Power",71. In a pataphysic sense, anti-power means, in the last analysis, the agony of power or, in other words, the abyssal power of human agony itself in the era of late neocapitalism. Paradoxically, although current global power or hegemony no longer denotes a world of dominators and dominated people (as in the previous case of dominion) ${ }^{72}$, hegemonic capitalist power becomes more and more ambiguous, unstable and agonizing in a very deadly way. According to Baudrillardian lesson, that must be taught carefully, this desperate hegemonic power does not need to be undermined from outside, i.e. revolution or explosion, a Lenin-like frontal attack against Versailles, because, ontologically, theologically and poetically speaking, it is an abyssal entropic form of a power/anti-power nature which is quite possible to be overturned from inside, i.e. involution and implosion ${ }^{73}$.

According to Jean Baudrillard, the advent of hegemony instead of domination (see the Figure below) must be considered as "a triple jump, a three-part sacrifice" that both dramatically and in a redemptive manner (as God's redeeming grace) overturn the traditional economic, political and philosophical illusions of Western modernity itself. It is worth reminding here that the French anti-philosopher perceives virtuality as a critical kind of 'integral reality' that dispels modern illusions forever. In this vein, Baudrillardian simulacra must be seen as a positive sense of illusion ${ }^{74}$ :

“1) Capital surpasses itself and turns against itself in the sacrifice of value (the economic illusion). 2) Power turns against itself in the sacrifice of representation (the democratic illusion). 3) The entire system turns against itself in the sacrifice of reality (the metaphysical illusion),, 75 .

\begin{tabular}{|c|c|}
\hline Domination as a model of power & Hegemony as a model of anti-meta-power \\
\hline A master-slave relationship & $\begin{array}{l}\text { No longer dominants and dominated, but a } \\
\text { kind of an-nex-ation, i.e. nexus (=networks). } \\
\text { Everybody is trapped in the network and } \\
\text { submits to this hegemony }\end{array}$ \\
\hline That is to say a dual relationship & $\begin{array}{l}\text { Now, everyone is an accomplice. The end of } \\
\text { We are both victims and accomplices }\end{array}$ \\
\hline $\begin{array}{l}\text { A symbolic model of power. It has an } \\
\text { exterior character, i.e. representation }\end{array}$ & Hegemony is within us (internalisation) \\
\hline $\begin{array}{l}\text { Possibilities: explosion, revolution, } \\
\text { alienation, dis-alianation }\end{array}$ & $\begin{array}{l}\text { Hegemony uses complicity to lower } \\
\text { individuals and their desires and so devaluing } \\
\text { them even more. Nevertheless, we are no } \\
\text { alienated in the conventional sense. Alienation } \\
\text { is no longer the dominant problem (Marxism). } \\
\text { However, we still suffer. We suffer from an }\end{array}$ \\
\hline
\end{tabular}

\footnotetext{
${ }_{71}^{71}$ Jean Baudrillard, The Agony of Power, Semiotext(e), Los Angeles, 2010 (Translated by Ames Hodges).

72 Jean Baudrillard, The Agony of Power, Semiotext(e), Los Angeles, 2010, p. 33 (Translated by Ames Hodges).

${ }^{73}$ Richard G. Smith (ed.), The Baudrillard Dictionary, Edinburgh University Press, Edinburgh, 2005, p. 105.

${ }^{74}$ William Pawlett, “Illusion', In: Richard G. Smith (ed.), The Baudrillard Dictionary, Edinburgh University Press, Edinburgh, 2005, p. 99.

75 Jean Baudrillard, The Agony of Power, Semiotext(e), Los Angeles, 2010, p. 41 (Translated by Ames Hodges).
} 


\begin{tabular}{|l|l|}
\hline & $\begin{array}{l}\text { irreversible vertigo. We are drawn to the black } \\
\text { hole. This black hole is called by Baudrillard } \\
\text { 'integral reality'. It is both destructive and } \\
\text { redeeming }\end{array}$ \\
\hline $\begin{array}{l}\text { Agonistic or active optimism (political } \\
\text { engagement) }\end{array}$ & $\begin{array}{l}\text { No hope for any socio-political resistance. } \\
\text { Passive behaviour or pessimism (apolitical } \\
\text { attitude) is coming to the fore as an implosive } \\
\text { involution and/or inertia. }\end{array}$ \\
\hline Domination phase & $\begin{array}{l}\text { Hegemony is the next phase of domination. } \\
\text { Actually, hegemony brings domination, and } \\
\text { therefore alienation, to an end }\end{array}$ \\
\hline Evil & \begin{tabular}{l} 
Good (as an Evil which speaks about Itself) \\
\hline
\end{tabular} \\
\hline
\end{tabular}

Figure: From domination to hegemony in the era of turbo-capitalism ${ }^{76}$

Within the Baudrillardian pataphysical poetics, this agony of power is described as a rough and tough process of both cannibalization and carnivalization; a quasi-ritual orgy, i.e. turbo-capitalism and hegemony, where every meaning, every representation, every sociopolitical agent or every symbol is liquidated as if a paradoxical kind, both destructive and constructive, of an ontotheological sacrifice in the suicidal Minotaur of power ${ }^{77}$. Therefore, mockery, irony, masquerade, cynicism and parody are the main expressions of this neocapitalist social void where not only the capital and the power but the entire system turns against itself by sacrificing the Real per se. If this approach is an ironic return to the Platonic transcendence then this 'perfect crime', which is the disappearance of reality itself, could be conceived as "Baudrillard's version of the death of god" not in the conventional subjective sense of Nietzsche but through "'an objective and (...) autonomous process, the 'destiny of the object'. There remains, one might say, the 'real' process through which the real has disappeared (...) What we used to call history and society have themselves become simulacra. This is why, for Baudrillard", Andrew Wernick points out, "the old project of liberation and transformation, together with all critical efforts [he means apparently 'Critical Theory'] to unmask the real, have become meaningless. Needed rather are 'fatal strategies' (...) which challenge the system to challenge itself, 78 .

By liquidating (to note here only Zygmunt Bauman's relevant problématique of liquidity) the traditional economic, democratic and metaphysical illusions, both turbocapitalism and hegemonic power lead to the end of the social and the political which are redefined by Baudrillard as a shadow; as a hyperspace; or as a hegemonic form, i.e. the Real that represents itself as a Virtual. By refusing itself, power is at the same time a form of antimeta-power. As it is well-known, Baudrillard presents this paradoxical transformation of reality into hyperreality in the late modernity of turbo-capitalism under the allegorical name of white terror (i.e. the Janus face of Good and Evil) ${ }^{79}$. Hence, beyond Good and Evil, this hyperreal world power is a Nietzsche-inspired negative ontotheology of social and political

\footnotetext{
${ }^{76}$ Jean Baudrillard, The Agony of Power, Semiotext(e), Los Angeles, 2010, pp. 33-56 (Translated by Ames Hodges).

77 Jean Baudrillard, Carnival and Cannibal, Seagull Books, London and New York, 2010 and Ross Abbinnett, “'Carnival and Cannibal', In: Theory, Culture and Society, No. 4, Vol. 28 (2011), pp. 145-156.

78 Andrew Wernick, “Real', In: Richard G. Smith (ed.), The Baudrillard Dictionary, Edinburgh University Press, Edinburgh, 2005, pp. 180-181.

79 Jean Baudrillard, The Agony of Power, Semiotext(e), Los Angeles, 2010, p. 59 (Translated by Ames Hodges).
} 
power (i.e. ontologia and theologia negativa) where the desire of hegemonic power, or, in other words, the so-called 'will of power' in the Nietzschean philosophy, leads messianically and eschatologically speaking to her agonizing self-destruction (i.e. the agony of power itself). In accordance with Baudrillard's own poetical and deconstructive prosa

"Negativity reemerges as irony, mocking and auto-liquidation internal to power. This is how the slave devours and cannibalizes the Master from the inside. As power absorbs the negative, it is devoured by what it absorbs. There is justice in reversibility. A catastrophic dialectic has replaced the "work of the negative", 80 .

White terrorism is that kind of terrorism which the state power produces itself in the era of turbo-capitalism, hegemony, transpolitics and transparency of evil. As far as Baudrillard is concerned, this form of hegemonic neocapitalism or turbo-capitalism is a kind of anti-meta-power or a kind of transpolitical capitalism which has been intoxicated by its empty signifiers ${ }^{81}$. This is the historical moment of the absolute emptiness of politics or the aestheticization of traditional political representation and symbolical exchange. So to the extent that politics is no longer a process of political struggle and adversary, it has been transformed into a game of transparent goodness, i.e. a goodness without Good. Put it simply, according to Baudrillard, insofar as Evil has given its position to transparent good, transpolitics finds in the hyperreal specter of white terrorism its absolute simulacrum. In the pataphysic era of turbo-capitalism and transpolitics, terrorism is the apotheosis (or deification) of hyperreality, virtual reality and above all liquidation of every symbolical representation. 9/11 and onwards, turbo-capitalism must be seen as a kind of self-terrorism. The aestheticization of terrorism via mass media and 'TV reality' paved the way for the advent of post-Totalitarian era. Terrorism becomes the kernel of transpolitics. Everything has been contaminated by the empty signifier of terrorism. "Every extension of hegemony", Baudrillard writes in a prophetic, messianic and eschatological sense, 'is also an extension of terror (....) All global culture is cannibalized by terror, by the discourse of terror" ${ }^{\prime \prime 2}$.

To put it another way, it could be said that metapolitics itself is a kind of terrorism. Hegemony is just the virtual and aesthetical surface of this post-Totalitarian world. Terrorism means first and foremost the terrorization of people via mass media, televisions, social networks etc. Ontotheological speaking, the whole thing looks like a postmodern Apocalypse. For Jean Baudrillard, the transparency of evil in the post-Totalitarian world mainly signifies the passage from a master-slave model of power (i.e. domination) to a novel mode of subjection (i.e. hegemony) in which the peoples are accomplices with their selfdestruction. Probably, this is not the typical category of Marxian alienation, but a transpolitical liquidation of any traditional political representation and symbolization where politics is defined as a sui generis passive and at the same time implosive action of selfcannibalization. Albert Camus defines this paradoxical situation as a true ontotheological event in which human comes to power in a state of self-apotheosis through a metaphysical rebellion ${ }^{83}$.

\footnotetext{
${ }^{80}$ Jean Baudrillard, The Agony of Power, Semiotext(e), Los Angeles, 2010, p. 59 (Translated by Ames Hodges).

${ }^{81}$ Ernesto Laclau, Emancipation(s), Verso, London and New York, 1996, p.

${ }^{82}$ Jean Baudrillard, The Agony of Power, Semiotext(e), Los Angeles, 2010, p. 94 and p. 96 respectively (Translated by Ames Hodges).

${ }^{83}$ Albert Camus, The Rebel, Penguin Books, London and New York, 2000, p. 29 (Translated by Anthony Bower).
} 
This is the moment, in which the people, in a Machiavellian, Spinozian or Lefortean sense $^{84}$, is entering into the pataphysical spectrum of self-destruction (i.e. Spinoza's 'conatus' or, otherwise, these Freudian drives and/or instincts of eros and death) ${ }^{85}$. It goes without saying that this is a paradoxical kind of power, both passive and active, both Good and Evil, entirely transparent, where the fatal strategy and/or condition of self-terrorism dominates. Both turbo-capitalism and transpolitics, as far as Jean Baudrillard is concerned, must be seen as the realized metonymy of the empty signifier of self-terrorism (i.e. white terrorism). The critical question that arises here is whether this is a typical Left-driven social analysis, or, as lots of Baudrillard's critics accuse him, it is the typical expression of radical conservatism, i.e. a sophisticated and elegant Nietzsche-inspired pessimism? In other words, what is at stake is whether the people can efficiently resist against itself. Hence, the significant issue of politics in the era of turbo-capitalism is not about of 'what is to be done' but "who is going to do it ${ }^{, 86}$. From this viewpoint, transpolitics in the era of hegemony continues to remain a question of agency ${ }^{87}$.

In this Baudrillardian grotesque-like transpolitical theory of anti-meta-power, even in an indirect way, the French anti-philosopher poses or, even better, raises the critical and sometimes thorny question of agency. To put it differently, Baudrillard brings to light the loss of political subject in the era of turbo-capitalism, transpolitics and transparency of symbolical exchange. Hence, politics is defined as transpolitics chiefly because lacks every characteristic of activity and by extension of symbolical representation. In fact, the citizens have been trapped into the broken mirror of simulacra and simulation. From a psychoanalytic point of view, the Lacanian 'mirror stage' (stade du miroir) has never led to the stage of political symbolization ${ }^{88}$. The empty mirror of anti-meta-power indicates the emptiness of agency in the period of transpolitics. In this regard, it could be claimed that the late Baudrillard returns to a Marx-like philosophy of history concerning the way humans can change their lives actively instead of interpreting it: "The philosophers have only interpreted the world in various ways; the point is to change it",89. So, paraphrasing David Harvey, it could be said that the enigma of turbo-capitalism mainly becomes an enigma of sociopolitical agency in the era of self-terrorism ${ }^{90}$. If there is even a small chance to reconstruct the mirror of politics, Jean Baudrillard, by showing us the bizarre consequences of our passivity in the hyperreality of transpolitics, suggests to analyze thoroughly and in-depth this peculiar phenomenon of the 'agony of power'. The agony of power is really the agony of the socio-political subject in the edge of abyss, i.e. the transparency of evil ${ }^{91}$. In this vein, if this post-foundational structure of transpolitics signifies the absolute ontotheological openness of

${ }^{84}$ Claude Lefort, Machiavelli in the Making, Northwestern University Press, Evanston, Illinois, 2015, pp. 240279.

${ }^{85}$ Sigmund Freud, Beyond the Pleasure Principle, Dover Publications, Inc., United States, 2015.

${ }^{86}$ Spiros Makris, "Discourses of revolutionary subject in contemporary Marxism. Critical reflections through Ernesto Laclau and Chantal Mouffe's oeuvre", In: Theoria \& Praxis. International Journal of Interdisciplinary Thought, No. 1, Vol. 3, (2015), pp. 1-10.

${ }^{87}$ Zygmunt Bauman, In Search of Politics, Polity Press, Cambridge, 2006, p. 58.

${ }^{88}$ Jacques Lacan, Écrits. The FIRST Complete Edition in English, W. W. Norton \& Company, Inc., New York and London, 2006, p. 75.

${ }^{89}$ Karl Marx with Friedrich Engels, The German Ideology. Includes: Theses on Feuerbach and the Introduction to the Critique of Political Economy, Prometheus Books, New York, 1998, p. 571.

${ }^{90}$ David Harvey, The Enigma of Capital and the Crises of Capitalism, Oxford University Press, Oxford, 2010, p. 215.

91 Jean Baudrillard, The Transparency of Evil. Essays on Extreme Phenomena, Verso, London and New York, 1993 (Translated by James Benedict). 
politics towards a liquid modernity ${ }^{92}$, then, by the same token, it could be argued that this new ambivalent and contingent post-Totalitarian era gives us the opportunities to actively and consciously seek new forms of socio-political symbolization and representation away from the self-catastrophic parodic negativity of cannibalization, carnivalization and transparency of the political. Of course, this is not an easy way for us to efficiently deal with the problem of turbo-capitalism and of course this is not a naive proposal to pursue a new social utopia ${ }^{93}$. By contrast, it is a proper way to reconsider the question of political action today or, in other words, to grasp how we must re-establish our public spaces, i.e our republics in the etymological meaning of res publica (public affairs) ${ }^{94}$.

For Jean Baudrillard, the pataphysic phenomenon of cannibalization is when hegemonic power in the era of turbo-capitalism is turning against itself. In this case, power as an anti-meta-power moves beyond its ontotheological limits. Therefore, this hegemonic kind of anti-meta-power is by definition an unrestricted kind of power. This paradoxical development in late modernity, as happens also with the Baumanian approach, leads everything under a state of liquidation. From now on, there are no symbols, no representations, no tangible realities but only empty or floating signifiers of an unlimited carnivalization $^{95}$. The era of anti-meta-power brings to the fore the phenomenon of transpolitics. The prefix 'trans', in Baudrillardian thought, means the transparency of power. As power is empty of every symbolization and representation stays alone with itself. I fact, it tends to be a process of a boundless aestheticization. Paraphrased Walter Benjamin, it could be argued that anti-meta-power or transpolitics is the aestheticization of politics itself ${ }^{96}$. Mass media, entertainment, consumerism and seduction transfer politics of domination into a hegemony of parody, simulation and simulacra. Transpolitics absorbs symbols and representations; breaks the mirrors of clear reference between things and concepts and leads citizenry in the pataphysic state of passivity, inertia, apathy and silence ${ }^{97}$. As in the case of traditional fascism, in the era of turbo-capitalism, transpolitics turns into transparency of evil. Humans, without any mediation, appear themselves in the empty mirror of populism and demagogy. For Jean Baudrillard, silent citizens are absolutely accomplices in this new Apocalypse. Actually, Baudrillard, as an apocalyptic prophet, foretold the advent of contemporary populism and in this sense both the end of the social and politics. So, put it in a nutshell, cannibalization of politics means the end of politics through an aestheticization or a carnivalization of symbolic exchange. By taking seriously into consideration, Claude Lefort's theory of power as an empty space, it would be not an exaggeration to argue that Baudrillardian approach of turbo-capitalism and anti-meta-power could be conceived as an

92 Zygmunt Bauman, Liquid Modernity, Polity Press, Cambridge, 2000, p. 16; Oliver Marchart, PostFoundational Political Thought: Political Difference in Nancy, Lefort, Badiou and Laclau, Edinburgh University Press, Edinburg, 2007, p. 154; Oliver Marchart, Post-Foundational Theories of Democracy. Reclaiming Freedom, Equality, Solidarity, Edinburgh University Press, Edinburg, 2018 and Oliver Marchart, Thinking Antagonism. Political Ontology After Laclau, Edinburgh University Press, Edinburg, 2018.

93 Jean Baudrillard, Utopia Deferred. Writings for Utopie (1967-1978), Semiotext(e), Los Angeles, 2006, pp. 31-32 and pp. 61-63.

${ }^{94}$ Dana R. Villa, “Postmodernism and the Public Sphere’, In: American Political Science Review, No. 3, Vol. 86 (1992), pp. 712-721.

${ }_{95}$ Ernesto Laclau, Emancipation(s), Verso, London and New York, 1996, p. 36.

${ }^{96}$ Walter Benjamin, Selected Writings. Volume 3, 1935-1938, The Belknap Press of Harvard University Press, Cambridge, Massachusetts, and London, England, 2006, pp. 120-122 (Translated by Edmund Jephcott, Howard Eiland, and Others).

97 Jean Baudrillard, The Disappearance of Culture. Uncollected Interviews, Edinburgh University Press, Edinburgh, 2017 (Edited by Richard G. Smith and David B. Clarke). 
archetypic post-foundational social ontotheology about 'the political' in which hegemony, as power in a state of a virtual apotheosis, is trans-formed (see the prefix 'trans') into a pataphysic game of absolute risk and self-de(con)struction. In this regard, turbo-capitalism is conceived as a state of power risk and popular self-catastrophe. Therefore, the agony of hegemonic power paradoxically, ironically and eschatologically expresses the abyssal power of human agony in the age of silent masses and transpolitics. In Arendt's own terms, both cannibalization and carnivalization of hegemonic power signal the ontotheological advent of post-Totalitarian world of mass society and worldlessness ${ }^{98}$.

In his seminal book 'Carnival and Cannibal', Baudrillard analyzes further the phenomenon of transpolitics and the transparency of evil by putting the emphasis on the human accountability, i.e. human responsibility in the sense of an active and so thoughtfulness and prudent citizenship. Hence, if cannibalization means a humanity that cannibalizes itself or a humanity that has cannibalized the human condition as such, then this pataphysic human fatality (i.e. mortality) (of both cannibalization and carnivalization) can be changed only through a human society which could be break this vicious circle of turbocapitalism by stopping to consume itself as a zombie. This is a difficult change because, as Baudrillard clearly shows, the individual has been entrapped into this peculiar hyper-power of hegemony which lacks every kind of legitimation, representation and symbolization. Actually, to the extent that this is a world empty of masters and slaves, dominators and the dominated or hegemonizers and the hegemonized, the liberation is not just a kind of revolution or emancipation. If there is an optimistic opportunity for us to be set free from the fatal conditions of cannibalization and carnivalization this is the case of either a reflexive individual or a collective subject which could be rearrange the broken mirror of politics in terms of symbolical exchange and political representation. From this viewpoint, this kind of ontotheological, symbolical and political change means that we ought to deconstruct this transparent or ventriloquist evil which appears or speaks instead of us without us and finally against us. From a pure Heideggerian perspective, this definitely means that we must rethink the phenomenological and existential implications of modernity itself. In other words, it means that we must take seriously into account the critical relationship between the social and technological aspects of our lives that give birth to a special kind of political community that is not a power simulation but a polis in the Aristotelian or Arendtian sense or, as Zygmunt Bauman writes, a polis in the meaning of agora in which people act, speak and judge in concert producing an entire culture of symbolical exchange, corpo-real communication, deliberation, legitimation and political representation ${ }^{99}$.

In 1978, first in the French language and then in 1983 in the English speaking audience, Jean Baudrillard published his main socio-political manifesto with the very provocative title 'In the Shadow of the Silent Majorities or the End of the Social' ${ }^{100}$. It seems quite difficult almost impossible to grasp in-depth the so-called Baudrillardian 'transpolitical world ${ }^{101}$, without having previously to deal with this manifesto and its argumentation both on the end of the social and political in the era of hyperreality or turbo capitalism. As in the case of the Spinozian conatus, Baudrillard formulates a paradoxical (i.e. pataphysical) social

\footnotetext{
98 John Kiess, Hannah Arendt and Theology, Bloomsbury, London and New York, 2016, p. 95.

${ }^{99}$ Bauman Zygmunt, "From agora to the marketplace, and whereto from here?', In: Journal of Globalization Studies, No. 1, Vol. 2 (2011), pp. 3-14.

100 Jean Baudrillard, In the Shadow of the Silent Majorities Or The End Of The Social, Semiotext(e), Los Angeles, 2007 (Translated by Paul Foss, John Johnston, Paul Patton and Andrew Berardini).

${ }^{101}$ Paul Hegarty, Jean Baudrillard. Live Theory, Continuum, London, New York, 2004, p. 91.
} 
ontotheology or a theory of anti-meta-power in the postmodernity by using the implosive energy of the masses as an eschatological vehicle in order to bring to the fore the thorny question of agency in late capitalism. To put it in a nutshell, both the end of the social and the end of 'the political' signify first and foremost the tragic loss of agency in the era of transpolitics. Masses, in this transpolitical context, are characterized by the paradoxical strength of inertia and apathy. By and large, they look like a 'gigantic black hole', and this is undoubtedly one more example of Jean Baudrillard's idiosyncratic metaphorical and poetical expression $^{102}$, that absorbs everything, especially the famous Western signifiers of State, History, Culture and above all Meaning itself ${ }^{103}$. By cancelling every political representation, masses themselves represents the social void per se. As far as Jean Baudrillard is concerned, this is the human condition of simulation par excellence. In the era of transpolitics or, in other words, of turbo capitalism everything takes place in vacuo ${ }^{104}$. Paraphrasing the prophetic and messianic French anti-philosopher, it can be argued, both as a tragic and redeeming conclusion, that transpolitical masses in the hegemonic era of turbo-capitalism (or the 'multitude' in the Spinozian jargon) are "a black hole that engulfs the social", 105.

\section{BIBLIOGRAPHY}

[1] Albert Camus, The Rebel, Penguin Books, London and New York, 2000 (Translated by Anthony Bower).

[2] Andrew Wernick, "Real", In: Richard G. Smith (ed.), The Baudrillard Dictionary, Edinburgh University Press, Edinburgh, 2005.

[3] Claude Lefort, Democracy and Political Theory, Polity Press, Cambridge, 1988.

[4] Claude Lefort, Machiavelli in the Making, Northwestern University Press, Evanston, Illinois, 2015.

[5] Cornelius Castoriadis, The Castoriadis Reader, Blackwell Publishers, Oxford, 1997 (Translated by David Ames Curtis).

[6] Dana R. Villa, “Postmodernism and the Public Sphere', In: American Political Science Review, No. 3, Vol. 86 (1992), pp. 712-721.

[7] David Harvey, The Enigma of Capital and the Crises of Capitalism, Oxford University Press, Oxford, 2010.

[8] David M. Kotz, The Rise and Fall of Neoliberal Capitalism, Harvard University Press, USA, 2015.

[9] Douglas Kellner, “Theorizing Globalization', In: Sociological Theory, No. 3, Vol. 20 (2002), pp. 285-305.

[10] Ernesto Laclau, Emancipation(s), Verso, London and New York, 1996.

[11] Franz Rosenzweig, The Star of Redemption, The University of Wisconsin Press, 2005.

[12] Friedrich Nietzsche, Thus Spoke Zarathustra, Penguin Books, London and New York, 1969 (Translated by R. J. Hollingdale).

[13] Hannah Arendt, Crises of the Republic, Harcourt Brace Jovanovich, Inc., New York, 1972.

[14] Hannah Arendt, The Origins of Totalitarianism, Schocken Books, New York, 2004.

[15] Hannah Arendt, Between Past and Future. Eight Exercises in Political Thought, Penguin Books, New York, 2006.

[16] Ian Buchanan, Dictionary of Critical Theory, Oxford University Press, Oxford, 2010.

[17] Jacques Lacan, Écrits. The FIRST Complete Edition in English, W. W. Norton \& Company, Inc., New York and London, 2006.

\footnotetext{
102 Jean Baudrillard, In the Shadow of the Silent Majorities Or The End Of The Social, Semiotext(e), Los Angeles, 2007, p. 40 (Translated by Paul Foss, John Johnston, Paul Patton and Andrew Berardini).

103 Jean Baudrillard, In the Shadow of the Silent Majorities Or The End Of The Social, Semiotext(e), Los Angeles, 2007, p. 36 (Translated by Paul Foss, John Johnston, Paul Patton and Andrew Berardini).

104 Jean Baudrillard, In the Shadow of the Silent Majorities Or The End Of The Social, Semiotext(e), Los Angeles, 2007, p. 36 (Translated by Paul Foss, John Johnston, Paul Patton and Andrew Berardini).

105 Jean Baudrillard, In the Shadow of the Silent Majorities Or The End Of The Social, Semiotext(e), Los Angeles, 2007, p. 37 (Translated by Paul Foss, John Johnston, Paul Patton and Andrew Berardini).
} 
[18] Jean Baudrillard, “The Ecstasy of Communication', In: Hal Foster (ed.), The Anti-Aesthetic. Essays on Postmodern Culture, Bay Press, Port Townsend, Washington, 1987 (Translated by John Johnston).

[19] Jean Baudrillard, Selected Writings, Polity Press, Cambridge, 1988 (Edited by Mark Poster).

[20] Jean Baudrillard, Seduction, St. Martin's Press, New York, 1990.

[21] Jean Baudrillard, The Transparency of Evil. Essays on Extreme Phenomena, Verso, London and New York, 1993 (Translated by James Benedict).

[22] Jean Baudrillard, Symbolic Exchange and Death, Sage Publications, London, Thousand Oaks, New Delhi, 1993 (Translated by Iain Hamilton Grant).

[23] Jean Baudrillard, Simulacra and Simulation, The University of Michigan Press, Ann Arbor, 1994 (Translated by Sheila Faria Glaser).

[24] Jean Baudrillard, The Perfect Crime, Verso, London and New York, 1996 (Translated by Chris Turner).

[25] Jean Baudrillard, The Consumer Society. Myths and Structures, Sage Publications, London, Thousand Oaks, New Delhi, 1999.

[26] Jean Baudrillard, The Vital Illusion, Columbia University Press, New York, 2000.

[27] Jean Baudrillard, The Conspiracy of Art. Manifestos, Interviews, Essays, Semiotext(e), New York, 2005 (Translated by Ames Hodges).

[28] Jean Baudrillard, Utopia Deferred. Writings for Utopie (1967-1978), Semiotext(e), Los Angeles, 2006.

[29] Jean Baudrillard, In the Shadow of the Silent Majorities Or The End Of The Social, Semiotext(e), Los Angeles, 2007 (Translated by Paul Foss, John Johnston, Paul Patton and Andrew Berardini).

[30] Jean Baudrillard, Fatal Strategies, Semiotext(e), Los Angeles, 2007, p. 25 and p. 97 (Translated by Philippe Beitchman \& W. G. J. Niesluchowski).

[31] Jean Baudrillard, Forget Foucault, Semiotext(e), Los Angeles, 2007 (Translated by Nicole Dufresne).

[32] Jean Baudrillard, The Agony of Power, Semiotext(e), Los Angeles, 2010 (Translated by Ames Hodges).

[33] Jean Baudrillard, Carnival and Cannibal, Seagull Books, London and New York, 2010.

[34] Jean Baudrillard, The Spirit of Terrorism, Verso, London and New York, 2012 (Translated by Chris Turner).

[35] Jean Baudrillard, The Disappearance of Culture. Uncollected Interviews, Edinburgh University Press, Edinburgh, 2017 (Edited by Richard G. Smith and David B. Clarke).

[36] Jonathan Smith, "Perfect Crime', In: Richard G. Smith (ed.), The Baudrillard Dictionary, Edinburgh University Press, Edinburgh, 2005.

[37] John Kiess, Hannah Arendt and Theology, Bloomsbury, London and New York, 2016.

[38] Karl Marx with Friedrich Engels, The German Ideology. Includes: Theses on Feuerbach and the Introduction to the Critique of Political Economy, Prometheus Books, New York, 1998.

[39] Karl Marx, Later Political Writings, Cambridge, Cambridge University Press, 2002 (Edited and translated by Terrell Carver).

[40] Matthias Benzer, "Metaphysics", In: Richard G. Smith (ed.), The Baudrillard Dictionary, Edinburgh University Press, Edinburgh, 2005.

[41] Michael Roberts, "Postmodernism and the linguistic turn", In: Peter Lambert and Phillipp Schofield (eds), Making History: An Introduction to the history and practices of a discipline, Routledge, Oxford and New York, 2004.

[42] Oliver Marchart, Post-Foundational Political Thought: Political Difference in Nancy, Lefort, Badiou and Laclau, Edinburgh University Press, Edinburgh, 2007.

[43] Oliver Marchart, Post-Foundational Theories of Democracy. Reclaiming Freedom, Equality, Solidarity, Edinburgh University Press, Edinburgh, 2018.

[44] Oliver Marchart, Thinking Antagonism. Political Ontology After Laclau, Edinburgh University Press, Edinburgh, 2018.

[45] Paul Hegarty, “Jean Baudrillard', In: Jon Simons (ed.), Contemporary Critical Theorists. From Lacan to Said, Edinburgh University Press, Edinburgh, 2004.

[46] Paul Hegarty, Jean Baudrillard. Live Theory, Continuum, London, New York, 2004.

[47] Ronaldo Munck, Marx@ 2000. Late marxist perspectives, Zed Books, London \& New York, 2000 . 
[48] Razmig Keucheyan, The Left Hemisphere. Mapping Critical Theory Today, Verso, London and New York, 2013.

[49] Richard J. Lane, Jean Baudrillard, London and New York, Routledge, 2001.

[50] Richard G. Smith (ed.), The Baudrillard Dictionary, Edinburgh University Press, Edinburgh, 2005.

[51] Ross Abbinnett, "Carnival and Cannibal”, In: Theory, Culture and Society, No. 4, Vol. 28 (2011), pp. 145-156.

[52] Sigmund Freud, Beyond the Pleasure Principle, Dover Publications, Inc., United States, 2015

[53] Spiros Makris, "Discourses of revolutionary subject in contemporary Marxism. Critical reflections through Ernesto Laclau and Chantal Mouffe's oeuvre', In: Theoria \& Praxis. International Journal of Interdisciplinary Thought, No. 1, Vol. 3, (2015), pp. 1-10.

[54] Spiros Makris, "Politics, Ethics and Strangers in the $21^{\text {st }}$ Century. Fifteen critical reflections on Jacques Derrida's concept of hos(ti)pitality', In: Theoria \& Praxis. International Journal of Interdisciplinary Thought, No. 1, Vol. 5 (2017), pp. 1-21.

[55] Spiros Makris, "Aristotle in Hannah Arendt's Republicanism. From homo faber to homo politicus', In: Annuaire International De Droits De L' Homme, 2015-2016, Issy-les-Moulineaux Cedex, Paris: L.G.D.J. lextensoéditions, Volume IX (2017), pp. 535-563.

[56] Spiros Makris, "European Demos, Citizenship and Migrants in a Globalized World. Some Critical Reflections from a Habermasian Perspective", In: Marco Caselli and Guia Gilardoni (eds), Globalization, Supranational Dynamics and Local Experiences, Palgrave Macmillan, New York, 2018.

[57] Stuart Sim, Fifty Key Postmodern Thinkers, Routledge, London and New York, 2013.

[58] Walter Benjamin, Selected Writings. Volume 3, 1935-1938, The Belknap Press of Harvard University Press, Cambridge, Massachusetts, and London, England, 2006, pp. 120-122 (Translated by Edmund Jephcott, Howard Eiland, and Others).

[59] Walter Benjamin, Illuminations, The Bodley Head, London, 2015.

[60] William Merrin, "Jean Baudrillard", In: John Scott (ed.), Fifty Key Sociologists. The Contemporary Theorists, Routledge, London and New York, 2007.

[61] William Pawlett, "Illusion”, In: Richard G. Smith (ed.), The Baudrillard Dictionary, Edinburgh University Press, Edinburgh, 2005.

[62] Zygmunt Bauman, Liquid Modernity, Polity Press, Cambridge, 2000.

[63] Zygmunt Bauman, In Search of Politics, Polity Press, Cambridge, 2006.

[64] Bauman Zygmunt, "From agora to the marketplace, and whereto from here?', In: Journal of Globalization Studies, No. 1, Vol. 2 (2011), pp. 3-14. 